\title{
Risk Assessment of Insecticides Used in Tomato to Control Whitefly on the Predator Macrolophus basicornis (Hemiptera: Miridae)
}

\author{
Thaís Fagundes Matioli *, Mariana Rosa da Silva, Juliano de Bastos Pazini, Geovanny Barroso (D), \\ Júlia Gabriela Aleixo Vieira and Pedro Takao Yamamoto
}

check for

updates

Citation: Matioli, T.F.; da Silva, M.R.; de Bastos Pazini, J.; Barroso, G.; Vieira, J.G.A.; Yamamoto, P.T. Risk Assessment of Insecticides Used in Tomato to Control Whitefly on the Predator Macrolophus basicornis (Hemiptera: Miridae). Insects 2021, 12, 1092. https://doi.org/10.3390/ insects12121092

Academic Editor: Alberto Pozzebon

Received: 3 November 2021

Accepted: 3 December 2021

Published: 7 December 2021

Publisher's Note: MDPI stays neutral with regard to jurisdictional claims in published maps and institutional affiliations.

Copyright: (c) 2021 by the authors. Licensee MDPI, Basel, Switzerland. This article is an open access article distributed under the terms and conditions of the Creative Commons Attribution (CC BY) license (https:/ / creativecommons.org/licenses/by/ $4.0 /)$.
Department of Entomology and Acarology, "Luiz de Queiroz" College of Agriculture, University of São Paulo (ESALQ/USP), Piracicaba 13418-900, Brazil; marianarosa.silva@usp.br (M.R.d.S.); julianopazini@usp.br (J.d.B.P.); geovannybarroso@usp.br (G.B.); julia.aleixo@usp.br (J.G.A.V.); pedro.yamamoto@usp.br (P.T.Y.)

* Correspondence: thaisf.matioli@usp.br

Simple Summary: The whitefly Bemisia tabaci is a problem in tomato crops worldwide. The use of chemicals is one method to control this pest. Predators from the family Miridae have been used in Europe as biological control agents. We tested the insecticides most often used to control B. tabaci in tomato fields in Brazil for compatibility with the native Brazilian mirid Macrolophus basicornis. The results showed that regarding lethality, buprofezin, cyantraniliprole and spiromesifen were reduced-risk insecticides. Acetamiprid, bifenthrin, etofenprox + acetamiprid and pyriproxyfen + acetamiprid were considered broad-spectrum insecticides. The insecticides were also tested to be classified ecologically and were found to be safe, except for acetamiprid that was moderately toxic. Overall, our findings indicated that it is possible to use M. basicornis as a biological agent to control B. tabaci in tomato crops by means of pest management strategies that are compatible with agrochemicals in current use.

Abstract: The generalist mirid predator Macrolophus basicornis may contribute to Integrated Pest Management (IPM) of Bemisia tabaci in tomato crops. It is important to know the compatibility of the chemicals used to control this pest with this promising biological control agent. Seven insecticides were tested to investigate their toxicity to the predator. For four of the products, the $\mathrm{LC}_{50}$ for adults were determined. Buprofezin, cyantraniliprole and spiromesifen did not cause lethality and were classified as harmless. Acetamiprid, bifenthrin, etofenprox + acetamiprid and pyriproxyfen + acetamiprid caused acute toxicity and were classified as harmful. $\mathrm{LT}_{50}$ for all harmful insecticides were relatively low, ranging from 1.8 to 3.2 days. Moreover, these four insecticides have low $\mathrm{LC}_{50}$, with acetamiprid $\left(0.26 \mathrm{mg}\right.$ a.i. $\left.\mathrm{L}^{-1}\right)$ as the lowest, followed by bifenthrin $\left(0.38 \mathrm{mg}\right.$ a.i. $\left.\mathrm{L}^{-1}\right)$, etofenprox + acetamiprid $\left(4.80 \mathrm{mg}\right.$ a.i. $\left.\mathrm{L}^{-1}\right)$ and pyriproxyfen + acetamiprid $\left(8.71 \mathrm{mg}\right.$ a.i. $\left.\mathrm{L}^{-1}\right)$. However, the calculated risk quotient (RQ) values demonstrated that these insecticides were mostly ecologically safe for this predator, except for acetamiprid, classified as slightly to moderately toxic. The present study can contribute to the use of M. basicornis as a biological control agent on tomato crops and to compatible use with the insecticides tested, according to IPM strategies.

Keywords: biological control; ecotoxicology; integrated pest management; natural enemy

\section{Introduction}

The family Miridae contains a significant number of predator species used in augmentative biological control in tomato crops [1,2]. The genus Macrolophus has been used in Europe to control Tuta absoluta (Meyrick) (Lepidoptera: Gelechiidae) and Bemisia tabaci (Genn.) Biotype B (Hemiptera: Aleyrodidae), the main tomato pests [2]. In Brazil, Macrolophus basicornis (Stal) (Hemiptera: Miridae) has a considerable potential to be reared in 
biofactories and released in the field to control the whitefly B. tabaci [3-9]. Some studies have shown that this natural enemy can easily establish in the field because of its zoophytophagy, a trait that aids it to remain where it is released without the presence of prey, since it can consume the sap from the crop [7,10-12]. Despite the benefits of using this natural enemy, B. tabaci is controlled by different insecticides, due to its direct and indirect damage on tomato $[13,14]$, which may harm this possible new biological control agent.

It is important to understand the acute toxicity of insecticides used in pest control and the ecological risks to natural enemies prior to introducing a new biological control agent in any crop $[15,16]$. Hence, the development of new strategies in integrated pest management (IPM) programs involves compatibility studies of tactics, especially chemical and biological control [17]. Recent studies have demonstrated the effects of chemical products used to control T. absoluta on the predator M. basicornis [18-21]. Studies are needed to assess the toxic effects on $M$. basicornis using chemical products against $B$. tabaci.

Both the whitefly and the mirid predator have sucking mouthparts that introduce the stylets into the tissues [4,14]. Many insecticides used to control B. tabaci are systemic and can affect the mirid, which feeds on plant tissue as a source of water and nutrients. The insecticides function by contact exposure to reach the pest nymphs and adults that remain on the leaves and residues may harm $M$. basicornis individuals on treated surfaces. Chemical groups have different modes of action on pests. Many are broad-spectrum and can kill a wide range of many natural enemies [22,23], including $M$. basicornis. Other, reduced-risk insecticides are more selective to the predators and cause no or low lethal effect $[18,20,24]$.

The first step of risk assessment is to determine the acute toxicity of commonly used insecticides to natural enemies in a laboratory bioassay, using the recommended field rates. One way to classify the chemicals is according to the International Organization for Biological and Integrated Control of Noxious Animals and Plants (IOBC), evaluating their lethal effect on the target species to determine the physiological selectivity [25]. Another important classification is the risk quotient (RQ), which classifies the chemicals that will be ecologically selective, related to the ways that the insects are exposed in the field $[26,27]$. This evaluation can help to determine the possible risks of pesticides to natural enemies in the field, quantifying the concentrations for parasitoids and predators, as estimated for Encarsia formosa Gahan (Hymenoptera: Aphelinidae) [28], three Trichogramma species (Hymenoptera: Trichogrammatidae) $[27,29]$ and the mirid Cyrtorhinus lividipennis Reuter (Hemiptera: Miridae) [26,30].

The present study was conducted to assess the acute toxicity and RQ of seven insecticides commonly used to control B. tabaci in tomato crops on the mirid predator $M$. basicornis. We investigated the acute toxicity and median lethal concentration $\left(\mathrm{LC}_{50}\right)$ of the insecticides that are currently most often used (acetamiprid, bifenthrin, buprofezin, cyantraniliprole, etofenprox + acetamiprid, pyriproxyfen + acetamiprid and spiromesifen). We hypothesized that it is possible to find compatible insecticides with the predator to enable it to be used as a biological control agent, adding to the IPM tactics.

\section{Materials and Methods}

\subsection{Insects}

Individuals of $M$. basicornis were obtained from the established rearing colony, more than eight generations old, at the Laboratory of Insect Biology in the Entomology and Acarology Department, "Luiz de Queiroz" College of Agriculture (ESALQ/USP), Piracicaba, Brazil. The insects were originally collected in the state of Minas Gerais, Brazil $\left(21^{\circ} 08.596^{\prime} \mathrm{S}\right.$ and $45^{\circ} 03.466^{\prime} \mathrm{W}, 808 \mathrm{~m}$ altitude) in tobacco (Nicotiana tabacum L.) fields. The method used was proposed by Bueno et al. [4], in which adults and nymphs were kept on tobacco plants in acrylic cages $(60 \times 30 \times 30 \mathrm{~cm})$ and fed with eggs of Ephestia kuehniella Zeller (Lepidoptera: Pyralidae) offered ad libitum. The cages were kept in a climate-controlled room at $25 \pm 2{ }^{\circ} \mathrm{C}, 70 \pm 10 \% \mathrm{RH}$ and 12:12 $\mathrm{h}$ (L:D). Before the experiments, adults were kept in cages with tobacco plants for oviposition. After $48 \mathrm{~h}$, the plants were moved to 
an insect-free cage. This made it possible to obtain predators with the same age, either third-instar nymphs or adults ( $<3$ days old) from the plants [20].

\subsection{Insecticides}

The commercial insecticides are registered for the control of B. tabaci in Brazilian tomato crops and were tested on M. basicornis at the highest recommended field doses (Table 1).

Table 1. Active ingredient, trade name, chemical group, exposure route, mode of action and field application rate of the principal insecticides used to control Bemisia tabaci in tomato crops in Brazil.

\begin{tabular}{|c|c|c|c|c|c|c|c|}
\hline \multirow{2}{*}{$\begin{array}{c}\text { Active } \\
\text { Ingredient }\end{array}$} & \multirow{2}{*}{ Trade Name } & \multirow{2}{*}{$\begin{array}{l}\text { Chemical } \\
\text { Group }\end{array}$} & \multirow{2}{*}{$\begin{array}{l}\text { Exposure } \\
\text { Route }\end{array}$} & \multirow{2}{*}{ Mode of Action } & \multicolumn{2}{|c|}{$\begin{array}{c}\text { Field Rate } \\
\text { (g or } \mathrm{mL} 100 \mathrm{~L}^{-1} \text { ) }\end{array}$} & \multirow{2}{*}{$\begin{array}{l}\text { Field Rate } \\
\left(\mathrm{g}^{\text {a.i. }} \mathrm{ha}^{-1}\right)\end{array}$} \\
\hline & & & & & a.i. & c.p. & \\
\hline Acetamiprid & Mospilan WG & Neonicotinoid & Systemic & $\begin{array}{l}\text { Competitive modulator } \\
\text { of nicotinic } \\
\text { acetylcholine receptors }\end{array}$ & 21.8 & 30 & 87 \\
\hline Bifenthrin & Seizer $^{\circledR} 10$ EC & Pyrethroid & $\begin{array}{l}\text { Contact and } \\
\text { ingestion }\end{array}$ & $\begin{array}{l}\text { Sodium channel } \\
\text { modulator }\end{array}$ & 1.5 & 15 & 15 \\
\hline Buprofezin & Applaud ${ }^{\circledR} 25 \mathrm{WP}$ & Thiadiazinone & Contact & $\begin{array}{l}\text { Chitin synthesis } \\
\text { inhibitors }\end{array}$ & 50 & 200 & 500 \\
\hline Cyantraniliprole & Benevia $^{\circledR} 10$ OD & Diamide & $\begin{array}{l}\text { Systemic and } \\
\text { contact }\end{array}$ & $\begin{array}{l}\text { Ryanodine receptor } \\
\text { modulator }\end{array}$ & 12.5 & 125 & 50 \\
\hline $\begin{array}{l}\text { Etofenprox + } \\
\text { acetamiprid }\end{array}$ & $\begin{array}{l}\text { Eleitto }^{\circledR} 30+ \\
16.7 \text { OD }\end{array}$ & $\begin{array}{l}\text { Pyrethroid + } \\
\text { Neonicotinoid }\end{array}$ & $\begin{array}{l}\text { Systemic and } \\
\text { contact }\end{array}$ & $\begin{array}{c}\text { Sodium channel } \\
\text { modulator }+ \\
\text { competitive modulator } \\
\text { of nicotinic } \\
\text { acetylcholine receptors }\end{array}$ & $12+6.8$ & 40 & $120+66.8$ \\
\hline $\begin{array}{l}\text { Pyriproxyfen }+ \\
\text { acetamiprid }\end{array}$ & $\begin{array}{l}\text { Privilege }{ }^{\circledR} 10+ \\
20 \text { OD }\end{array}$ & $\begin{array}{c}\text { Pyridyloxypropyl } \\
\text { ether }+ \\
\text { Neonicotinoid }\end{array}$ & $\begin{array}{l}\text { Contact, } \\
\text { ingestion, } \\
\text { translaminar } \\
\text { and systemic }\end{array}$ & $\begin{array}{c}\text { Juvenile hormone } \\
\text { mimics + Nicotinic } \\
\text { acetylcholine receptor } \\
\text { (NACHR) competitive } \\
\text { modulators }\end{array}$ & $3+6$ & 30 & $30+60$ \\
\hline Spiromesifen & Oberon ${ }^{\circledR} 24$ SC & Cetoenol & $\begin{array}{l}\text { Contact and } \\
\text { ingestion }\end{array}$ & $\begin{array}{l}\text { Inhibitors of acetyl CoA } \\
\text { carboxylase }\end{array}$ & 14.4 & 60 & 144 \\
\hline
\end{tabular}

EC (Emulsifiable Concentrate); OD (Oil Dispersion); SC (Suspension Concentrate); WG (Water-dispersible Granules); WP (Wettable Powder); c.p. (commercial product); a.i. (active ingredient).

\subsection{Insecticide Exposure for Testing Acute Toxicity}

Five-week-old tomato plants (cv. Santa Clara) grown in greenhouse conditions were sprayed with each of the insecticides listed in Table 1, using a hand-held sprayer (Light Sprayer-Breeze, $500 \mathrm{~mL}$ capacity; Guarany; São Paulo, Brazil) until the run-off point ( $\sim 50 \mathrm{~mL}$ per plant). Distilled water was used as the control treatment [31].

After drying for $2 \mathrm{~h}$, the leaves were collected from treated plants and transferred to the laboratory. Each leaf had its petiole inserted into a flask $(20 \mathrm{~mL})$ filled with water to maintain turgidity during the bioassay and provided a lid with an opening for the petiole (Supplementary Material Figure S1). Each tube was transferred to a cage (12 cm high $\times 5 \mathrm{~cm}$ diameter) (PET crystal, $500 \mathrm{~mL}$; Copozan, Otávio Dalazen, Brazil), with each unit representing one repetition. In each cage, 15 adults of M. basicornis ( $<3$ days old) or 15 third-instar nymphs were released and the cage was covered with voile fabric to prevent accumulation of toxic gases and retain the insects. M. basicornis individuals were fasted for $24 \mathrm{~h}$ before the beginning of the experiments to ensure that they started to feed as soon as they came into contact with the insecticide residues. As an alternative food source for M. basicornis, E. kuehniella eggs (0.4 g) were offered per cage. The design was randomized with 6 replicates per treatment.

M. basicornis were left on the treated leaves for $72 \mathrm{~h}$ under controlled room conditions $\left(25 \pm 2{ }^{\circ} \mathrm{C}, 70 \pm 10 \% \mathrm{RH}\right.$ and 12:12 h L: D). After this period, untreated leaves were 
provided to assess the survival rate and median lethal time $\left(\mathrm{LT}_{50}\right)$. The insects' survival was assessed every $24 \mathrm{~h}$. The insects were considered dead when they were unable to walk at least the distance of their own body length after being touched with a fine brush.

\subsection{Determination of $L C_{50}$ of Harmful Insecticides}

The median lethal concentration $\left(\mathrm{LC}_{50}\right)$ was estimated for those insecticides that were harmful to adults of M. basicornis in the acute toxicity test (Section 2.3). The procedures for the $\mathrm{LC}_{50}$ bioassays were similar to the methods in Section 2.3. The design was completely randomized, with 6 replicates per treatment and 15 M. basicornis adults ( $<3$ days old) in each cage. The bioassays were performed with different concentrations per insecticide, below the recommended field concentration (Table 1), according to procedures described by Finney [32]. The following insecticide concentrations (in $\mathrm{mg}$ a.i. $\mathrm{L}^{-1}$ ) were used: five concentrations of acetamiprid $(0.03,0.3,1.0,15$ and 30$)$; eight concentrations of bifenthrin $(0.015,0.075,0.15,0.75,1.5,7.5,15$ and 22.5$)$; six concentrations of etofenprox + acetamiprid $(0.18,0.93,9.34,18.68$ and 93.4$)$; and five concentrations of pyriproxyfen + acetamiprid $(0.09,0.45,0.9,4.5,9.0$ and 45.0$)$. Mortality was assessed $72 \mathrm{~h}$ after insecticides exposure to calculate the $\mathrm{LC}_{50}$ and the live insects were checked every $24 \mathrm{~h}$. The insects were considered dead when they were unable to move at least the distance of their own body length after being touched with a fine brush.

\subsection{Statistical Analysis}

The data for the total number of live insects per replicate after 24, 48 and $72 \mathrm{~h}$ were checked for normality and homoscedasticity using the Shapiro-Wilk and Bartlett tests. If the assumptions of ANOVA were met, one-way ANOVA with Scott-Knott post-hoc $(p<0.05)$ was used to ascertain differences among treatment means. If the data did not satisfy the normality and variance homogeneity, Kruskal-Wallis non-parametric one-way ANOVA with Dunn with Bonferroni correction post-hoc $(p<0.05)$ was used through the "ExpDes", "easyanova" and "dunn.test" packages in the R software [33]. The mortality percentage values after $72 \mathrm{~h}$ were corrected according to the Schneider-Orelli formula [34]: $M_{a}(\%)=\left[\left(M_{t}-M_{c}\right) /\left(100-M_{c}\right)\right] \times 100$, where $M_{a}$ is the corrected mortality, $M_{t}$ the mortality observed in the treatment and $\mathrm{M}_{\mathrm{C}}$ the control mortality.

The data for survival of mirids exposed to insecticides over time were analyzed using Kaplan-Meier estimators (Log-Rank method). The survival curves and the median lethal time $\left(\mathrm{LT}_{50}\right)$ were compared using the Holm-Sidak test, in SigmaPlot version 12.3 (Systat Software, San José, CA, USA).

The data obtained from the tests to estimate the $\mathrm{LC}_{50}$ were submitted to a binomial model with the log-logistic regression (drfit) function for dose-response analysis in the statistical program R [33,35].

\subsection{Toxicity Classification}

Insecticides were classified in the toxicological categories of residual effects for tests in extended laboratory analysis, with the corrected mortality $\left(\mathrm{M}_{\mathrm{a}}\right)$ according to the IOBC, in which: class $1=$ harmless $\left(M_{a}<25 \%\right)$; class 2 = slightly harmful $\left(25 \leq M_{a} \leq 50 \%\right)$; class $3=$ moderately harmful $\left(51 \leq \mathrm{M}_{\mathrm{a}} \leq 75 \%\right)$; and class $4=$ harmful $\left(\mathrm{M}_{\mathrm{a}}>75 \%\right)$ [25].

To assess the ecological risk of the harmful insecticides, the risk quotient (RQ) was calculated from the $\mathrm{LC}_{50}$ values at $72 \mathrm{~h}$ after exposure, based on the formula: $\mathrm{RQ}=$ recommended field rate $\left(\mathrm{g}\right.$ a.i. $\left.\mathrm{ha}^{-1}\right) / \mathrm{LC}_{50}$ of beneficial insects $\left(\mathrm{mg}\right.$ a.i. $\left.\mathrm{L}^{-1}\right)$. To understand the ecological selectivity of the harmful insecticides, the calculated RQ values estimate the possible effect that can occur in the field. According to the results, the insecticides were classified as safe $(R Q<50)$, slightly to moderately toxic $(50<R Q \leq 2500)$ or dangerously toxic $(\mathrm{RQ}>2500)[26]$. 


\section{Results}

The toxicity for nymphs and adults of the insecticides tested varied widely. The number of live insects in the groups exposed to buprofezin, cyantraniliprole and spiromesifen were similar to the control treatment, while the number of live insects exposed to acetamiprid, bifenthrin, etofenprox + acetamiprid and pyriproxyfen + acetamiprid significantly differed from the other treatments for both third-instar nymphs (Table 2) and adults (Table 3). The data obtained for the most lethal insecticides showed an increasing toxicity over time for nymphs ( $24 \mathrm{~h}: \chi^{2}=37.3, d f=7, p<0.001 ; 48 \mathrm{~h}: \chi^{2}=36.7, d f=7, p<0.001$; $\left.72 \mathrm{~h}: \chi^{2}=39.0, d f=7, p<0.001\right)$ (Table 2$)$ and for adults $(24 \mathrm{~h}: \mathrm{F}=34.9, d f=7, p<0.001$; 48 h: $\mathrm{F}=34.9, d f=7, p<0.001 ; 72 \mathrm{~h}: \mathrm{F}=34.9, d f=7, p<0.001$ ) (Table 3).

Table 2. Number of live third-instar nymphs (mean $\pm \mathrm{SE}$ ) of Macrolophus basicornis $(24,48$ and $72 \mathrm{~h}$ ) after contact with insecticide residues on tomato leaves, corrected mortality $\left(\mathrm{M}_{\mathrm{a}}\right)$ after $72 \mathrm{~h}$ and IOBC classification of insecticides.

\begin{tabular}{|c|c|c|c|c|c|}
\hline \multirow{2}{*}{ Treatment } & \multicolumn{3}{|c|}{ Number of Live Nymphs $(n=15)$} & \multirow{2}{*}{$M_{a}(\%) *$} & \multirow{2}{*}{ Class ${ }^{1}$} \\
\hline & $24 \mathrm{~h}$ & $48 \mathrm{~h}$ & $72 \mathrm{~h}$ & & \\
\hline Control & $14.5 \pm 0.3 \mathrm{a}$ & $14.0 \pm 0.3 \mathrm{a}$ & $13.8 \pm 0.3 \mathrm{a}$ & - & - \\
\hline Acetamiprid & $3.3 \pm 1.7 \mathrm{~b}$ & $1.0 \pm 0.7 \mathrm{~b}$ & $0.2 \pm 0.2 \mathrm{~b}$ & 99.9 & 4 \\
\hline Bifenthrin & $4.2 \pm 1.3 \mathrm{~b}$ & $0.7 \pm 0.5 \mathrm{~b}$ & $0.0 \pm 0.0 \mathrm{~b}$ & 100.0 & 4 \\
\hline Buprofezin & $14.5 \pm 0.2 \mathrm{a}$ & $14.0 \pm 0.2 \mathrm{a}$ & $13.8 \pm 0.3 \mathrm{a}$ & 0.0 & 1 \\
\hline Cyantraniliprole & $14.5 \pm 0.2 \mathrm{a}$ & $14.0 \pm 0.5 \mathrm{a}$ & $13.6 \pm 0.5 \mathrm{a}$ & 0.8 & 1 \\
\hline Etofenprox + acetamiprid & $4.0 \pm 0.9 \mathrm{~b}$ & $0.7 \pm 0.3 b$ & $0.2 \pm 0.2 b$ & 99.9 & 4 \\
\hline Pyriproxyfen + acetamiprid & $3.0 \pm 1.1 \mathrm{~b}$ & $1.7 \pm 0.9 \mathrm{~b}$ & $1.2 \pm 0.9 \mathrm{~b}$ & 87.4 & 4 \\
\hline Spiromesifen & $14.8 \pm 0.2 \mathrm{a}$ & $14.6 \pm 0.2 \mathrm{a}$ & $14.0 \pm 0.4 \mathrm{a}$ & 0.0 & 1 \\
\hline$x^{2}$ & 37.3 & 37.6 & 39.0 & - & - \\
\hline$d f$ & 7 & 7 & 7 & - & - \\
\hline$p$ & $<0.001$ & $<0.001$ & $<0.001$ & - & - \\
\hline
\end{tabular}

Means followed by the same letter in a column do not differ by the Bonferroni test. ${ }^{*}$ Corrected mortality $\left(\mathrm{M}_{\mathrm{a}}\right)$ by the Schneider-Orelli formula [34]. ${ }^{1}$ Toxicological class according to IOBC ("International Organization for Biological and Integrated Control of Noxious Animals and Plants, West Palearctic Regional Section") in which: class $1=$ harmless $\left(M_{a}<25 \%\right)$; class $2=$ slightly harmful $\left(25 \leq \mathrm{M}_{\mathrm{a}} \leq 50 \%\right)$; class $3=$ moderately harmful $\left(51 \leq \mathrm{M}_{\mathrm{a}} \leq 75 \%\right)$; and class $4=$ harmful $\left(\mathrm{M}_{\mathrm{a}}>75 \%\right)$ [25].

Table 3. Number of live adults (mean \pm SE) of Macrolophus basicornis (24, 48 and $72 \mathrm{~h}$ ) after contact with insecticide residues on tomato leaves, corrected mortality $\left(\mathrm{M}_{\mathrm{a}}\right)$ after $72 \mathrm{~h}$ and IOBC classification of insecticides.

\begin{tabular}{|c|c|c|c|c|c|}
\hline \multirow{2}{*}{ Treatment } & \multicolumn{3}{|c|}{ Number of Live Adults $(n=15)$} & \multirow{2}{*}{$M_{a}(\%) *$} & \multirow{2}{*}{ Class $^{1}$} \\
\hline & $24 \mathrm{~h}$ & $48 \mathrm{~h}$ & $72 \mathrm{~h}$ & & \\
\hline Control & $14.5 \pm 0.2 \mathrm{a}$ & $14.5 \pm 0.2 \mathrm{a}$ & $14.3 \pm 0.3 \mathrm{a}$ & - & - \\
\hline Acetamiprid & $4.1 \pm 1.1 \mathrm{c}$ & $2.2 \pm 0.9 c$ & $0.2 \pm 0.2 c$ & 98.6 & 4 \\
\hline Bifenthrin & $6.8 \pm 0.8 b$ & $5.2 \pm 0.8 \mathrm{~b}$ & $2.8 \pm 0.3 b$ & 80.3 & 4 \\
\hline Buprofezin & $14.0 \pm 0.4 \mathrm{a}$ & $14.0 \pm 0.4 \mathrm{a}$ & $14.0 \pm 0.4 \mathrm{a}$ & 2.1 & 1 \\
\hline Cyantraniliprole & $14.3 \pm 0.3 \mathrm{a}$ & $14.0 \pm 0.4 \mathrm{a}$ & $13.8 \pm 0.5 \mathrm{a}$ & 3.5 & 1 \\
\hline Etofenprox + acetamiprid & $6.2 \pm 0.9 \mathrm{~b}$ & $2.6 \pm 1.0 \mathrm{c}$ & $0.5 \pm 0.3 c$ & 96.5 & 4 \\
\hline Pyriproxyfen + acetamiprid & $7.8 \pm 0.9 \mathrm{~b}$ & $5.2 \pm 0.9 \mathrm{~b}$ & $1.8 \pm 0.5 \mathrm{~b}$ & 87.4 & 4 \\
\hline Spiromesifen & $14.5 \pm 0.2 \mathrm{a}$ & $14.3 \pm 0.2 \mathrm{a}$ & $14.3 \pm 0.2 \mathrm{a}$ & 0.0 & 1 \\
\hline CV (\%) & 17.9 & 19.8 & 12.9 & - & - \\
\hline$F$ & 34.9 & 60.9 & 288.2 & - & - \\
\hline$d f$ & 7 & 7 & 7 & - & - \\
\hline$p$ & $<0.001$ & $<0.001$ & $<0.001$ & - & - \\
\hline
\end{tabular}

Means followed by the same letter in a column do not differ by the Scott-Knott test. ${ }^{*}$ Corrected mortality $\left(\mathrm{M}_{\mathrm{a}}\right)$ by the Schneider-Orelli formula [34]. ${ }^{1}$ Toxicological class according to IOBC ("International Organization for Biological and Integrated Control of Noxious Animals and Plants, West Palearctic Regional Section") in which: class $1=$ harmless $\left(\mathrm{M}_{\mathrm{a}}<25 \%\right)$; class $2=$ slightly harmful $\left(25 \leq \mathrm{M}_{\mathrm{a}} \leq 50 \%\right)$; class $3=$ moderately harmful $\left(51 \leq \mathrm{M}_{\mathrm{a}} \leq 75 \%\right)$; and class $4=$ harmful $\left(\mathrm{M}_{\mathrm{a}}>75 \%\right)[25]$. 
After $72 \mathrm{~h}$ of exposure of third-instar nymphs to insecticide residues on tomato leaves, buprofezin, cyantraniliprole and spiromesifen caused less than 1\% mortality (Table 2). For acetamiprid, bifenthrin, etofenprox + acetamiprid and pyriproxyfen + acetamiprid, mortality ranged from $91.3 \%$ to $100 \%$ (Table 2). For adults, spiromesifen, buprofezin and cyantraniliprole caused 0, 2.1 and 3.5\% mortality, respectively (Table 3). Pyriproxyfen + acetamiprid and bifenthrin reached 87.4 and $80.3 \%$ mortality, while etofenprox + acetamiprid and acetamiprid were the most harmful to adults, causing 96.5 and $98.6 \%$ mortality (Table 3).

According to IOBC classifications for acute toxicity, buprofezin, cyantraniliprole and spiromesifen are harmless $\left(\mathrm{M}_{\mathrm{a}}<25 \%=\right.$ class 1$)$ to nymphs and adults of $M$. basicornis. Acetamiprid, etofenprox + acetamiprid, pyriproxyfen + acetamiprid and bifenthrin are categorized as harmful $\left(\mathrm{M}_{\mathrm{a}}>75 \%=\right.$ class 4$)$ to this predator (Tables 2 and 3 ).

Survival rates for nymphs and adults after $72 \mathrm{~h}$ exposure to insecticides showed significant differences among treatments (nymphs: $\chi^{2}=686.96, d f=7, p<0.001$; adults: $\left.\chi^{2}=661.1, d f=7, p<0.001\right)$. Buprofezin, cyantraniliprole and spiromesifen were similar to the control (Table 4).

Table 4. Median lethal time ( $\left.\mathrm{LT}_{50}\right)$ in days for third-instar nymphs and adults of Macrolophus basicornis after $72 \mathrm{~h}$ in contact with insecticide residues on tomato leaves.

\begin{tabular}{ccccc}
\hline \multirow{2}{*}{ Treatment } & \multicolumn{4}{c}{ LT $\left._{\mathbf{5 0}} \mathbf{( 9 5 \%} \mathbf{C I}\right)$} \\
\cline { 2 - 5 } & \multicolumn{2}{c}{ Third-Instar Nymphs } & Adults \\
\hline Control & $55.0(48.8-61.1)$ & $\mathrm{a}$ & $26.4(23.7-29.1)$ & $\mathrm{a}$ \\
Acetamiprid & $1.9(1.5-2.2)$ & $\mathrm{b}$ & $2.2(1.7-2.5)$ & $\mathrm{b}$ \\
Bifenthrin & $2.1(1.7-2.5)$ & $\mathrm{b}$ & $3.2(2.6-3.8)$ & $\mathrm{b}$ \\
Buprofezin & $51.1(45.1-57.1)$ & $\mathrm{a}$ & $28.5(25.1-31.8)$ & $\mathrm{a}$ \\
Cyantraniliprole & $58.9(52.7-65.2)$ & $\mathrm{a}$ & $26.5(23.3-29.8)$ & $\mathrm{a}$ \\
Etofenprox + acetamiprid & $2.1(1.7-2.4)$ & $\mathrm{b}$ & $2.5(2.1-2.9)$ & $\mathrm{b}$ \\
Pyriproxyfen + acetamiprid & $1.8(1.5-2.1)$ & $\mathrm{b}$ & $3.2(2.8-3.6)$ & $\mathrm{b}$ \\
Spiromesifen & $55.4(49.5-61.3)$ & $\mathrm{a}$ & $22.6(20.5-24.7)$ & $\mathrm{a}$ \\
\hline$\chi^{2}$ & 6886.96 & & 661.1 & \\
$d f$ & 7 & & $<0.001$ & \\
$p$ & $<0.001$ & &
\end{tabular}

Means followed by the same letter in a column do not differ by the Holm-Sidak test. Cl: Confidence interval with $95 \%$ probability.

In comparison to the control group, the $\mathrm{LT}_{50}$ values of acetamiprid, etofenprox + acetamiprid, pyriproxyfen + acetamiprid and bifenthrin were reduced by the acute toxicity of these active ingredients, ranging from 1.8 to 2.1 days for nymphs and 2.2 to 3.2 days for adults (Table 4). In the survival curves, nymphs (Figure 1) were more vulnerable to the harmful insecticides than adults (Figure 2).

The median lethal concentration $\left(\mathrm{LC}_{50}\right)$ values are shown in Table 5 for acetamiprid, bifenthrin, etofenprox + acetamiprid and pyriproxyfen + acetamiprid, at $72 \mathrm{~h}$ after exposure of the adults to insecticide residues. Acetamiprid and bifenthrin had similar $\mathrm{LC}_{50}$ values and etofenprox + acetamiprid and pyriproxyfen + acetamiprid were less toxic and with similar LC $_{50}$ values, with overlapping confidence intervals from 3.28 to $11.25 \mathrm{mg}$ a.i. $\mathrm{L}^{-1}$ (Table 5). 


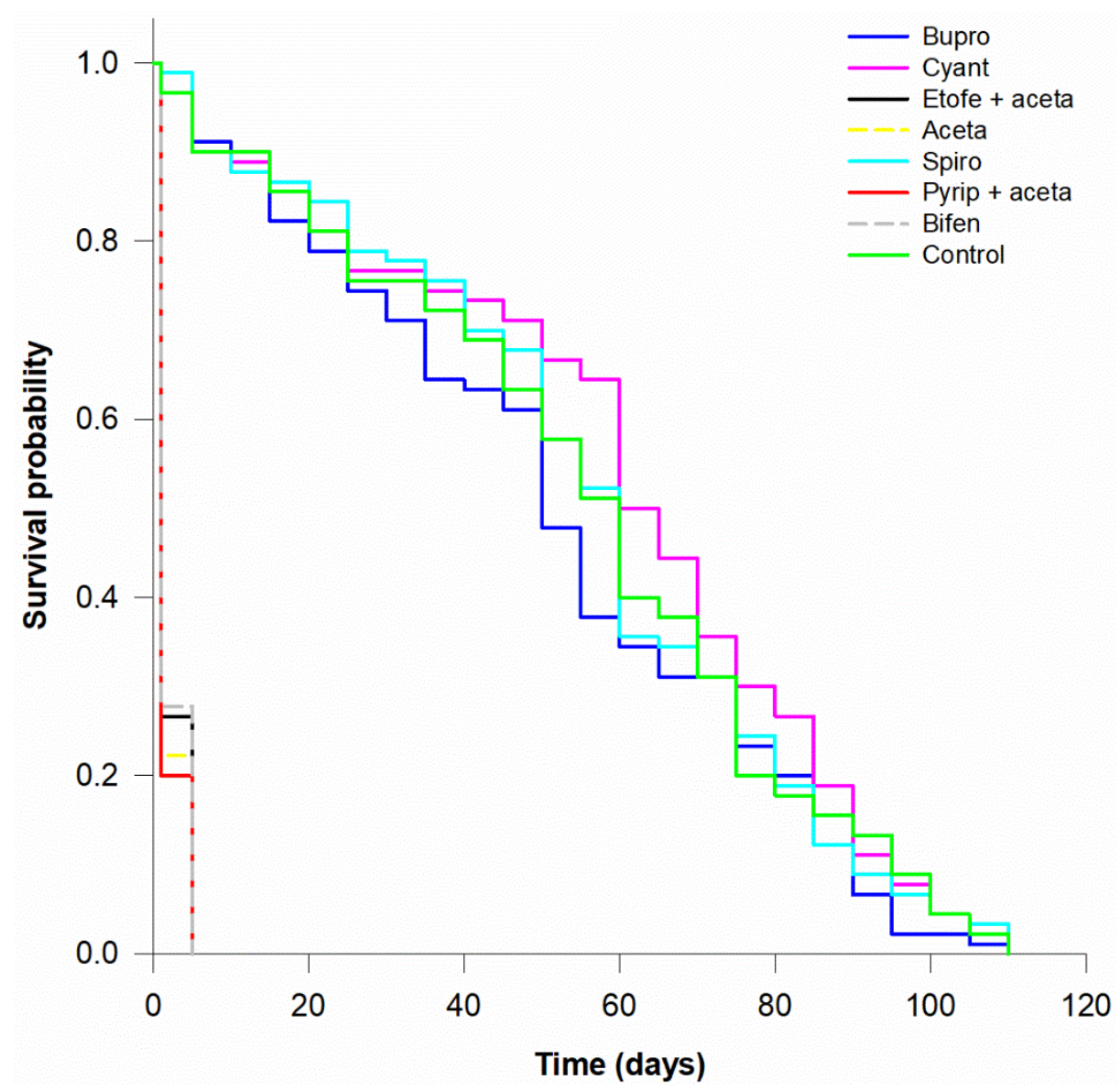

Figure 1. Survival curves for Macrolophus basicornis third-instar nymphs exposed to residues of buprofezin (Bupro), cyantraniliprole (Cyant), etofenprox + acetamiprid (Etofe + aceta), acetamiprid (Aceta), spiromesifen (Spiro), pyriproxyfen + acetamiprid (Pyrip + aceta), bifenthrin (Bifen) and control (water). The insects were in contact with the residues on tomato leaves for $72 \mathrm{~h}$ in controlled conditions.

Table 5. Median lethal concentration ( $\mathrm{LC}_{50}$ ) of insecticides for adults of Macrolophus basicornis after contact with residues on tomato leaves for $72 \mathrm{~h}$.

\begin{tabular}{|c|c|c|c|c|c|}
\hline Insecticides & $\begin{array}{l}\mathrm{LC}_{50}(95 \% \mathrm{CI}) \\
\left(\mathrm{mg} \text { a.i. } \mathrm{L}^{-1}\right)\end{array}$ & $x^{2}$ & $d f$ & $\mathbf{R Q}$ & Category * \\
\hline Acetamiprid & $0.26(0.16-0.35)$ & 11.58 & 4 & 334.6 & 2 \\
\hline Bifenthrin & $0.38(0.29-0.48)$ & 30.34 & 7 & 3.95 & 1 \\
\hline Etofenprox + acetamiprid & $4.80(3.28-6.31)$ & 32.07 & 5 & 38.91 & 1 \\
\hline Pyriproxyfen + acetamiprid & $8.71(6.18-11.25)$ & 65.86 & 4 & 10.33 & 1 \\
\hline
\end{tabular}

Data observed and predicted by the binomial model test with log-logistic regression. $p<0.0001$. Cl: confidence interval with $95 \%$ probability. ${ }^{*}$ Risk quotient categories according to the values at which the insecticides were classified as safe $(R Q<50)$, slightly to moderately toxic $(50<R Q \leq 2500)$, or dangerously toxic $(R Q>2500)[26]$

The RQ values of acetamiprid, bifenthrin, etofenprox + acetamiprid and pyriproxyfen + acetamiprid were 334.6, 3.95, 38.91 and 10.33, respectively. Etofenprox + acetamiprid, pyriproxyfen + acetamiprid and bifenthrin were classified as safe (category 1 ) and acetamiprid was classified as slightly to moderately toxic (category 2) (Table 5). 


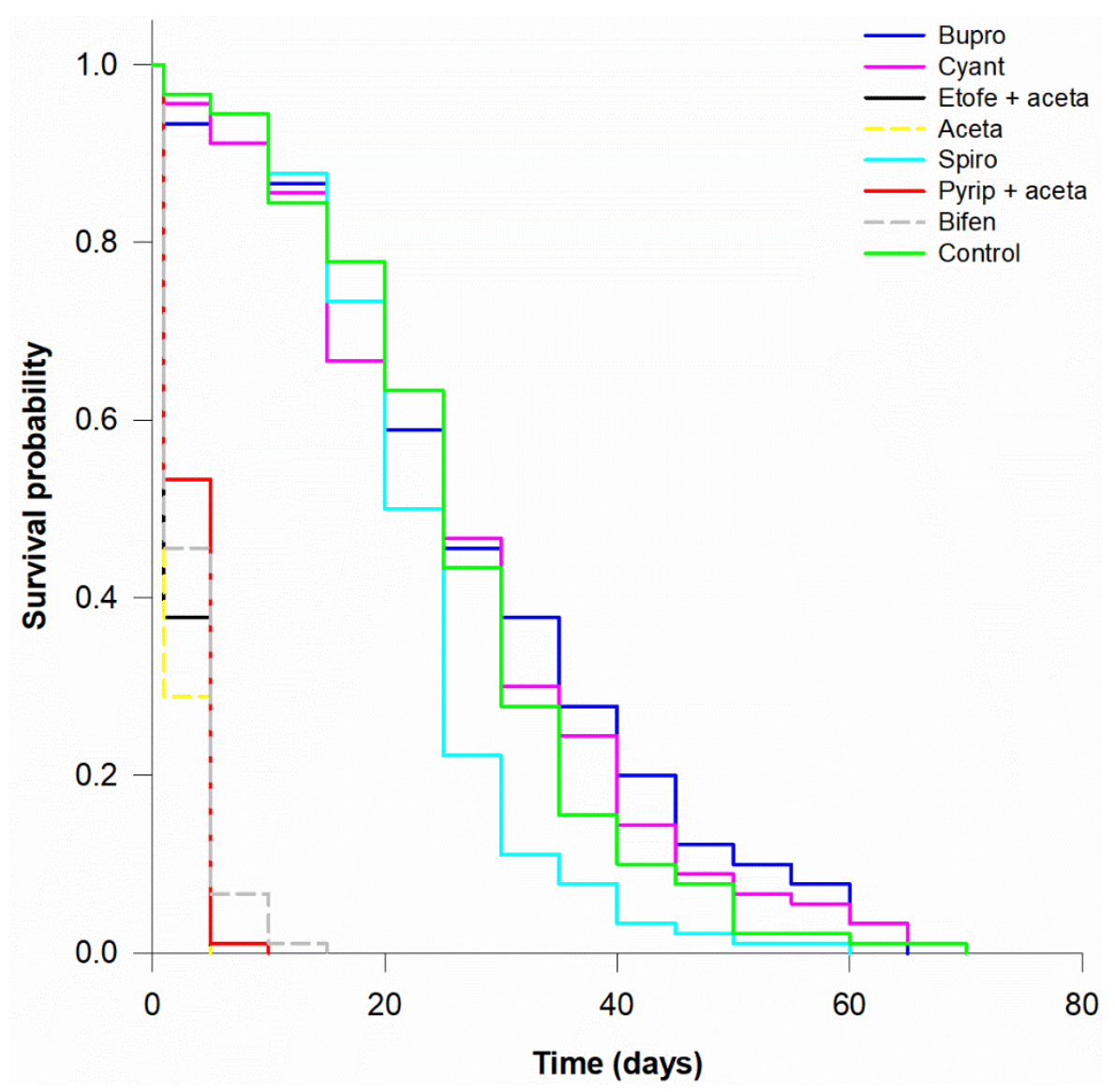

Figure 2. Survival curves for Macrolophus basicornis adults exposed to residues of buprofezin (Bupro), cyantraniliprole (Cyant), etofenprox + acetamiprid (Etofe + aceta), acetamiprid (Aceta), spiromesifen (Spiro), pyriproxyfen + acetamiprid (Pyrip + aceta), bifenthrin (Bifen) and control (water). The insects were in contact with the residues on tomato leaves for $72 \mathrm{~h}$ in controlled conditions.

\section{Discussion}

Mirid predators can help to manage B. tabaci in tomato crops [1,2]. The mirid M. basicornis preys on tomato pests in Brazil and may become a biological control agent for use in IPM programs $[3-6,36,37]$. Insecticides from different chemical groups and active ingredients for control of $B$. tabaci are commercially available. These products range from reducedrisk, which rarely harm natural enemies, to broad-spectrum, which are acutely toxic to natural enemies [38-40], compromising the implementation of IPM programs. To mitigate incompatibility issues, information is needed on the acute toxicity of the insecticides that are most often used to control B. tabaci and their effects on natural enemies.

According to our findings, buprofezin, cyantraniliprole and spiromesifen were considered reduced-risk insecticides for M. basicornis and classified as harmless according to the IOBC criteria (class 1), with $\mathrm{LT}_{50}$ values similar to the control treatment. Buprofezin is an insect growth regulator (IGR) that acts on the immature stage of sucking pests by inhibiting chitin synthesis and consequently the insects cannot molt normally [41,42]. Spiromesifen, which inhibits the acetyl CoA carboxylase, derived from tetronic and tetramic acids, interferes with the development, fecundity and lipid biosynthesis of the pest [43]. The diamide cyantraniliprole can act on nymphs and adults of sucking pests, inhibiting muscle contraction when the molecules bind to ryanodine receptors, resulting in starvation, paralysis and death $[44,45]$. In the present case, these insecticides did not cause acute toxicity to the natural enemy and the survival rate was also similar to the control. The results demonstrated that these insecticides are not harmful to M. basicornis in controlled conditions.

Similar results were found when residues of parallel insecticides did not cause high levels of acute toxicity to M. basicornis adults and nymphs [18-21]. Interestingly, Wanu- 
men et al. [18] showed that spiromesifen was innocuous to adults of M. basicornis exposed to residues on an inert substrate, but mortality increased in extended laboratory assays (sprayed on tomato leaves). In the present study, spiromesifen on tomato leaves retained the harmless acute effect in controlled conditions. This was elucidated by differences in the concentrations used, contributing to this negative effect. Therefore, at the semi-field level, it does not cause a lethal effect on this natural enemy [18] and probably will not be lethal in field conditions.

Similarly to the results for M. basicornis, buprofezin did not have a lethal effect on adults and nymphs of Pilophorus typicus Distant (Hemiptera: Miridae) under controlled conditions [46] or on Macrolophus caliginosus Wagner (Hemiptera: Miridae) under field conditions [47]. For the predator Deraeocoris brevis (Uhler) (Hemiptera: Miridae), cyantraniliprole was lethal to nymphs and was less toxic to adults [48]. These studies demonstrate the importance of knowing the acute toxicity of insecticides for the integrated use of biological and chemical controls in an IPM program. The physiological effects of reduced-risk insecticides may depend on the sensitivity of a species and its life stages and, therefore, it is important to test each active ingredient on each species of natural enemy [49]. Knowledge of the sensitivity of a species in tropical conditions is important for agriculture, considering that the sensitivity can differ depending on climate, temperature and light incidence [50].

Acetamiprid induces excitation until death, acting on neurons as a competitive modulator of the nicotinic acetylcholine receptor [51,52]. It is a chlorinated neonicotinoid which mainly acts by ingestion, due to its activity inside the plants, allowing systemic translocation in the sap vessels [53]. When sprayed on tomato leaves, it caused $80 \%$ mortality in adults of another mirid predator, Nesidiocoris tenuis (Reuter) (Hemiptera: Miridae) after five days of exposure [54]. In addition to acting systemically due to its hydrophobicity, acetamiprid also acts by contact $[55,56]$. On inert substrates in controlled conditions, acetamiprid caused 100\% mortality in M. caliginosus and Orius laevigatus (Fieber) (Hemiptera: Anthocoridae) [57]. Because mirid predators are omnivorous [58], systemic insecticides such as acetamiprid may affect this natural enemy by both the contact and ingestion routes of exposure.

Etofenprox and bifenthrin affect insects mainly through contact exposure $[59,60]$. Etofenprox and bifenthrin modulate the sodium channel in neuron axons, which keep the insect hyperexcited and also cause death [59]. Some pyrethroids tested on piercingsucking predators (Hemiptera) also caused acute toxicity [61,62], as did bifenthrin in this study. The active ingredient lambda-cyhalothrin is efficient in controlling the $B$. tabaci pest population in tomatoes, but significantly affected the survival of the mirid predator N. tenuis under laboratory conditions [61]. Deltamethrin demonstrated acute toxicity similar to bifenthrin, which caused $70 \%$ mortality in $N$. tenuis after contact with residues for more than $72 \mathrm{~h}$ [62]. Bifenthrin had a similar effect to our results when tested with a full concentration series bioassay in the laboratory, proving highly toxic to adults of Geocoris punctipes (Say) (Hemiptera: Geocoridae) and Orius insidiosus (Say) (Hemiptera: Anthocoridae) [63]. Pyrethroids are harmful to Podisus nigrispinus (Dallas) (Hemiptera: Pentatomidae), with high toxicity to nymphs and adults at the highest recommended rate in soybeans, even when mixed with low-risk insecticides [64].

Most acute toxicology studies do not address the ecological vulnerability of natural enemies to broad-spectrum pesticides and only assess whether they kill the insect, which is insufficient to recommend these pesticides in IPM programs. However, by determining the median lethal concentration $\left(\mathrm{LC}_{50}\right)$ for the most physiologically harmful insecticides to beneficial insects, it is possible to calculate the risk quotient (RQ) to determine the ecological risks of a given insecticide to a natural enemy. The insecticides evaluated here, especially acetamiprid and bifenthrin, showed quite low $\mathrm{LC}_{50}$ values. Calculating the RQ values for each formulation and considering the concentration of the active ingredients, most of the $R Q$ values were classified as safe $(R Q<50)$, except for acetamiprid, categorized as slightly to moderately toxic $(50<\mathrm{RQ} \leq 2500)$. These results are important to understand 
both the physiological and ecological risks together, in order to make decisions for IPM recommendations $[65,66]$.

This is the first study with $M$. basicornis to assess the acute toxicity and RQ values of the insecticides that are most often used to control B. tabaci in tomato crops. Other studies conducted with important natural enemies in different crop systems contributed useful information IPM $[26,27,35,67-69]$. Nevertheless, the researchers also made clear that certain insecticides tested, although classified as slightly to moderately harmful, should be thoroughly evaluated for inclusion in an IPM program, as they show high acute toxicity to the predator and other species.

Insecticides can act differently in each insect species and it is therefore important to study the pesticide formulations and their effect on the natural enemies that are most frequently found and released in the crops. As an example of the action of the same insecticides on different species, in the case of parasitoids of the genus Trichogramma, neonicotinoids and pyrethroids were tested to determine the $\mathrm{LC}_{50}$ and to calculate the $\mathrm{RQ}$ values [27]. For Trichogramma dendrolimi Matsumura, Trichogramma ostriniae Pang et Chen and Trichogramma chilonis Ishii (Hymenoptera: Trichogrammatidae), the $\mathrm{LC}_{50}$ values for acetamiprid were $0.32,1.37$ and $0.53 \mathrm{~g}$ a.i. $\mathrm{ha}^{-1}$ and the $\mathrm{RQ}$ values were $188.8,44.1$ and 114.0, respectively. Therefore, acetamiprid was categorized as slightly to moderately harmful to T. dendrolimi and T. chilonis (class 2) but safe for T. ostriniae (class 1) [27]. In the present study, the $\mathrm{LC}_{50}$ were also very low for all insecticides tested, similarly to the studies with Trichogramma species, but the $R Q$ values differed for acetamiprid, showing that these specific studies must be considered when assessing the insecticides' risks to a new species of natural enemy.

Taken together, the present results support the hypothesis that some of the insecticides tested were physiologically more harmful than others to the natural enemy. In addition, this study elucidated the ecological risks of those that proved to be physiologically harmful. Physiological and ecological risks must be considered when using IPM tools such as chemical and biological controls. If we consider only the physiological hazard, we eliminate all the other factors that can minimize the effect of these chemicals on non-target organisms in the field. These factors can potentially make pesticides more selective, based on, for example, formulation, placement, dosage and timing [64]. If the ecological risks are considered, there is a chance to match the methods to actual conditions in the tomato fields. It may be possible to use these insecticides with temporal and spatial separation [65]. IPM methods provide better results when most of the tools can be implemented in the field of the crop cycle [70].

\section{Conclusions}

The results obtained in controlled conditions for M. basicornis nymphs and adults are important to understand the action of insecticides on this natural enemy. Buprofezin, cyantraniliprole and spiromesifen were considered reduced-risk insecticides, but future studies should assess sublethal and transgenerational effects on this beneficial insect. Acetamiprid, bifenthrin, etofenprox + acetamiprid and pyriproxyfen + acetamiprid were harmful and considered broad-spectrum for M. basicornis. The physiological and ecological classifications for broad-spectrum insecticides were determined for M. basicornis adults and will support future IPM decisions. The RQ data provide insight into the ecological risk assessment for data acquired under more controlled conditions, but this needs to be confirmed with semi-field and field assays. Further studies are necessary to confirm compatibility of the methods with these active ingredients, such as in a greenhouse with regular insecticide spraying, to determine the persistence of the compound residues on tomato plants and the effects on the predator. It is also important to study crop management with these products to gather more accurate information. 
Supplementary Materials: The following are available online at https:/ / www.mdpi.com/article/ 10.3390 /insects12121092/s1, Figure S1: Detail of experimental units with flasks used to insert the petiole of each tomato leaf to maintain turgidity during the bioassay and the cage covered with voile fabric.

Author Contributions: Conceptualization, T.F.M. and P.T.Y.; data curation, J.d.B.P.; formal analysis, J.d.B.P.; funding acquisition, P.T.Y.; investigation, T.F.M. and M.R.d.S.; methods, T.F.M.; project administration, T.F.M. and P.T.Y.; resources, P.T.Y.; supervision, P.T.Y.; validation, J.d.B.P.; writingoriginal draft, T.F.M.; writing—review and editing, T.F.M., M.R.d.S., J.d.B.P., G.B., J.G.A.V. and P.T.Y. All authors have read and agreed to the published version of the manuscript.

Funding: This study was funded by the Brazilian Federal Agency for the Support and Evaluation of Graduate Education (CAPES) and the National Council for Scientific and Technological Development (CNPq) with financial support and award of a scholarship.

Institutional Review Board Statement: Not applicable.

Informed Consent Statement: Not applicable.

Data Availability Statement: The data presented in this study are available in the Supplementary Materials section.

Acknowledgments: The authors thank the Department of Entomology and Acarology of the "Luiz de Queiroz" College of Agriculture/University of São Paulo (ESALQ/USP), Piracicaba, São Paulo, Brazil; the Brazilian Federal Agency for the Support and Evaluation of Graduate Education (CAPES); the São Paulo Research Foundation (FAPESP) (grant 2019/26099-0); the National Council for Scientific and Technological Development (CNPq); and the Brazilian Research and Industrial Innovation Company (EMBRAPII/FUSP). They are grateful to Fernando Henrique Iost Filho and Janet W. Reid for help with the manuscript.

Conflicts of Interest: The authors declare no conflict of interest. The funders had no role in the design of the study; in the collection, analyses, or interpretation of data; in the writing of the manuscript, or in the decision to publish the results.

\section{References}

1. Cassis, G.; Schuh, R. Systematics, biodiversity, biogeography, and host associations of the Miridae (Insecta: Hemiptera: Heteroptera: Cimicomorpha). Annu. Rev. Èntomol. 2012, 57, 377-404. [CrossRef]

2. Van Lenteren, J.C. The state of commercial augmentative biological control: Plenty of natural enemies, but a frustrating lack of uptake. BioControl 2012, 57, 1-20. [CrossRef]

3. Bueno, V.H.P.; Montes, F.C.; Pereira, A.M.C.; Lins, J.C.; van Lenteren, J.C. Can recently found Brazilian hemipteran predatory bugs control Tuta absoluta? IOBC-WPRS Bull. 2012, 80, 63-67.

4. Bueno, V.H.P.; van Lenteren, J.; Lins, J.J.C.; Calixto, A.M.; Montes, F.C.; Silva, D.B.; Santiago, L.D.; Pérez, L.M. New records of Tuta absoluta (Meyrick) (Lepidoptera: Gelechiidae) predation by Brazilian Hemipteran predatory bugs. J. Appl. Èntomol. 2013, 137, 29-34. [CrossRef]

5. Bueno, V.H.P.; Calixto, A.M.; Montes, F.C.; van Lenteren, J.C. Population growth parameters of three Neotropical mirid predators (Hemiptera: Miridae) at five temperatures on tobacco with Ephestia kuehniella Zeller (Lepidoptera: Pyralidae) eggs as food. Israel J. Entomol. 2018, 48, 1-22. [CrossRef]

6. Bueno, V.H.P.; Montes, F.C.; Sampaio, M.V.; Calixto, A.M.; van Lenteren, J.C. Performance of immatures of three Neotropical Miridae at five different temperatures, reared on Ephestia kuehniella eggs on tobacco plants. Bull. Insectology 2018, 71, 77-87.

7. Silva, W.M.; Berger, M.; Bass, C.; Williamson, M.; Moura, D.M.; Ribeiro, L.M.; Siqueira, H.A. Mutation (G275E) of the nicotinic acetylcholine receptor $\alpha 6$ subunit is associated with high levels of resistance to spinosyns in Tuta absoluta (Meyrick) (Lepidoptera: Gelechiidae). Pestic. Biochem. Physiol. 2016, 131, 1-8. [CrossRef]

8. van Lenteren, J.C.; Hemerik, L.; Lins, J.C.; Bueno, V.H.P. Functional responses of three Neotropical mirid predators to eggs of Tuta absoluta on tomato. Insects 2016, 7, 34. [CrossRef]

9. $\quad$ van Lenteren, J.C.; Bueno, V.H.P.; Smit, J.; Soares, M.A.; Calixto, A.M.; Montes, F.C.; De Jong, P. Predation of Tuta absoluta eggs during the nymphal stages of three Neotropical mirid predators on tomato. Bull. Insectology 2017, 70, 69-74.

10. Castañé, C.; Arnó, J.; Gabarra, R.; Alomar, O. Plant damage to vegetable crops by zoophytophagous mirid predators. Biol. Control 2011, 59, 22-29. [CrossRef]

11. Calvo, F.J.; Lorente, M.J.; Stansly, P.A.; Belda, J.E. Preplant release of Nesidiocoris tenuis and supplementary tactics for control of Tuta absoluta and Bemisa tabaci in greenhouse tomato. Èntomol. Exp. Appl. 2012, 143, 111-119. [CrossRef] 
12. Lins, J.J.C.; Van Loon, J.J.A.; Bueno, V.H.P.; Lucas-Barbosa, D.; Dicke, M.; van Lenteren, J. Response of the zoophytophagous predators Macrolophus pygmaeus and Nesidiocoris tenuis to volatiles of uninfested plants and to plants infested by prey or conspecifics. BioControl 2014, 59, 707-718. [CrossRef]

13. De Barro, P.J.; Liu, S.-S.; Boykin, L.M.; Dinsdale, A.B. Bemisia tabaci: A statement of species status. Annu. Rev. Èntomol. 2011, 56, 1-19. [CrossRef]

14. Perring, T.M.; Stansly, P.A.; Liu, T.; Smith, H.A.; Andreason, S.A. Whiteflies: Biology, ecology, and management. In Sustainable Management of Arthropod Pests of Tomato; Wakil, W., Brust, G.E., Perring, T.M., Eds.; Elsevier: London, UK, 2018; pp. 73-110. [CrossRef]

15. Desneux, N.; Decourtye, A.; Delpuech, J.-M. The sublethal effects of pesticides on beneficial arthropods. Annu. Rev. Ėntomol. 2007, 52, 81-106. [CrossRef]

16. Barzman, M.; Bàrberi, P.; Birch, A.N.E.; Boonekamp, P.; Dachbrodt-Saaydeh, S.; Graf, B.; Hommel, B.; Jensen, J.E.; Kiss, J.; Kudsk, P.; et al. Eight principles of integrated pest management. Agron. Sustain. Dev. 2015, 35, 1199-1215. [CrossRef]

17. Naranjo, S.E.; Ellsworth, P.C.; Frisvold, G.B. Economic value of biological control in integrated pest management of managed plant systems. Annu. Rev. Èntomol. 2015, 60, 621-645. [CrossRef] [PubMed]

18. Wanumen, A.C.; Carvalho, G.A.; Medina, P.; Viñuela, E.; Adán, Á. Residual acute toxicity of some modern insecticides toward two mirid predators of tomato pests. J. Econ. Èntomol. 2016, 109, 1079-1085. [CrossRef]

19. Passos, L.C.; Soares, M.A.; Costa, M.A.; Michaud, J.; Freire, B.C.; Carvalho, G.A. Physiological susceptibility of the predator Macrolophus basicornis (Hemiptera: Miridae) to pesticides used to control of Tuta absoluta (Lepidoptera: Gelechiidae). Biocontrol Sci. Technol. 2017, 27, 1082-1095. [CrossRef]

20. Passos, L.C.; Soares, M.A.; Collares, L.J.; Malagoli, I.; Desneux, N.; Carvalho, G.A. Lethal, sublethal and transgenerational effects of insecticides on Macrolophus basicornis, predator of Tuta absoluta. Èntomol. Gen. 2018, 38, 127-143. [CrossRef]

21. Soares, M.A.; Passos, L.C.; de Campos, M.R.; Collares, L.J.; Desneux, N.; Carvalho, G.A. Side effects of insecticides commonly used against Tuta absoluta on the predator Macrolophus basicornis. J. Pest Sci. 2019, 92, 1447-1456. [CrossRef]

22. Ellsworth, P.C.; Martinez-Carrillo, J.L. IPM for Bemisia tabaci: A case study from North America. Crop. Prot. 2001, 20, 853-869. [CrossRef]

23. Naranjo, S.E. Conservation and evaluation of natural enemies in IPM systems for Bemisia tabaci. Crop. Prot. 2001, 20, 835-852. [CrossRef]

24. Dale, A.G.; Borden, M.A. Evaluation of reduced-risk insecticides to control chilli thrips (Thysanoptera: Thripidae) and conserve natural enemies on ornamental plants. Fla. Ėntomol. 2018, 101, 237-243. [CrossRef]

25. Hassan, S. International Organization for Biological and Integrated Control of Noxious Animals and Plants/Working Group "Pesticides and Beneficial Organisms" 1992. Guidelines for testing the effects of pesticides on beneficial organisms: Description of test methods. IOBC-WPRS Bull. 1992, XV,3.

26. Preetha, G.; Stanley, J.; Suresh, S.; Samiyappan, R. Risk assessment of insecticides used in rice on miridbug, Cyrtorhinus lividipennis Reuter, the important predator of brown planthopper, Nilaparvata lugens (Stal.). Chemosphere 2010, 80, 498-503. [CrossRef]

27. Cheng, S.; Lin, R.; Wang, L.; Qiu, Q.; Qu, M.; Ren, X.; Zong, F.; Jiang, H.; Yu, C. Comparative susceptibility of thirteen selected pesticides to three different insect egg parasitoid Trichogramma species. Ecotoxicol. Environ. Saf. 2018, 166, 86-91. [CrossRef] [PubMed]

28. Wang, Z.; Dai, P.; Yang, X.; Ruan, C.-C.; Biondi, A.; Desneux, N.; Zang, L.-S. Selectivity of novel and traditional insecticides used for management of whiteflies on the parasitoid Encarsia formosa. Pest Manag. Sci. 2019, 75, 2716-2724. [CrossRef]

29. Jiang, J.; Liu, X.; Huang, X.; Yu, X.; Zhang, W.; Zhang, X.; Mu, W. Comparative ecotoxicity of neonicotinoid insecticides to three species of Trichogramma parasitoid wasps (Hymenoptera: Trichogrammatidae). Ecotoxicol. Environ. Saf. 2019, $183,109587$. [CrossRef]

30. Liu, Y.; Li, X.; Zhou, C.; Liu, F.; Mu, W. Toxicity of nine insecticides on four natural enemies of Spodoptera exigua. Sci. Rep. 2016, 6, 39060. [CrossRef]

31. Arnó, J.; Gabarra, R. Side effects of selected insecticides on the Tuta absoluta (Lepidoptera: Gelechiidae) predators Macrolophus pygmaeus and Nesidiocoris tenuis (Hemiptera: Miridae). J. Pest Sci. 2011, 84, 513-520. [CrossRef]

32. Finney, D.J. Probit Analysis, 3rd ed.; Cambridge University: London, UK, 1971; 333p.

33. R Development Core Team. R: A Language and Environment for Statistical Computing. Vienna, Austria: R Foundation for Statistical Computing. 2020. Available online: https:// www.R-project.org/ (accessed on 24 October 2021).

34. Püntener, W. Manual for Field Trials in Plant Protection, 2nd ed.; Ciba-Geigy, Ltd.: Basel, Switzerland, 1981.

35. Ritz, C.; Baty, F.; Streibig, J.C.; Gerhard, D. Dose-response analysis using R. PLoS ONE 2015, 10, e0146021. [CrossRef]

36. Silva, D.B.; Bueno, V.H.P.; Van Loon, J.J.A.; Peñaflor, M.F.G.V.; Bento, J.M.S.; Van Lenteren, J.C. Attraction of three mirid predators to tomato infested by both the tomato leaf mining moth Tuta absoluta and the whitefly Bemisia tabaci. J. Chem. Ecol. 2017, 44, 29-39. [CrossRef]

37. van Lenteren, J.C.; Bueno, V.H.P.; Montes, F.C.; Hemerik, L.; De Jong, P.W. Adult lifetime predation of Tuta absoluta eggs by three Neotropical mirid predators on tomato. Bull. Insectology 2018, 71, 179-188.

38. Stansly, P.; Sánchez, P.; Rodríguez, J.; Cañizares, F.; Nieto, A.; Leyva, M.; Fajardo, M.; Suárez, V.; Urbaneja, A. Prospects for biological control of Bemisia tabaci (Homoptera, Aleyrodidae) in greenhouse tomatoes of southern Spain. Crop. Prot. 2004, 23, 701-712. [CrossRef] 
39. Koss, A.M.; Jensen, A.S.; Schreiber, A.; Pike, K.S.; Snyder, W.E. Comparison of predator and pest communities in Washington potato fields treated with broad-spectrum, selective, or organic insecticides. Environ. Èntomol. 2005, 34, 87-95. [CrossRef]

40. Togni, P.H.B.; Venzon, M.; de Souza, L.M.; Santos, J.P.C.R.; Sujii, E.R. Biodiversity provides whitefly biological control based on farm management. J. Pest Sci. 2018, 92, 393-403. [CrossRef]

41. Sohrabi, F.; Shishehbor, P.; Saber, M.; Mosaddegh, M. Lethal and sublethal effects of buprofezin and imidacloprid on Bemisia tabaci (Hemiptera: Aleyrodidae). Crop. Prot. 2011, 30, 1190-1195. [CrossRef]

42. Ullah, F.; Gul, H.; Yousaf, H.K.; Xiu, W.; Qian, D.; Gao, X.; Tariq, K.; Han, P.; Desneux, N.; Song, D. Impact of low lethal concentrations of buprofezin on biological traits and expression profile of chitin synthase 1 gene (CHS1) in melon aphid, Aphis gossypii. Sci. Rep. 2019, 9, 12291. [CrossRef] [PubMed]

43. Bretschneider, T.; Benet-Buchholz, J.; Fischer, R.; Nauen, R. Spirodiclofen and spiromesifen-novel acaricidal and insecticidal tetronic acid derivatives with a new mode of action. Chim. Int. J. Chem. 2003, 57, 697-701. [CrossRef]

44. Lahm, G.P.; Selby, T.P.; Freudenberger, J.H.; Stevenson, T.M.; Myers, B.J.; Seburyamo, G.; Smith, B.K.; Flexner, L.; Clark, C.E.; Cordova, D. Insecticidal anthranilic diamides: A new class of potent ryanodine receptor activators. Bioorganic Med. Chem. Lett. 2005, 15, 4898-4906. [CrossRef]

45. Sattelle, D.B.; Cordova, D.; Cheek, T.R. Insect ryanodine receptors: Molecular targets for novel pest control chemicals. Invertebr. Neurosci. 2008, 8, 107-119. [CrossRef] [PubMed]

46. Nakahira, K.; Kashitani, R.; Tomoda, M.; Kodama, R.; Ito, K.; Yamanaka, S.; Momoshita, M.; Arakawa, R. Side effects of vegetable pesticides on a predatory mirid bug, Pilophorus typicus Distant (Heteroptera: Miridae). Appl. Ėntomol. Zool. 2010, 45, $239-243$. [CrossRef]

47. Rasdi, M.Z.; Che Salmah, M.R.; Abu Hassan, A.; Hamady, D.; Hamaseh, A.; Fauziah, I. Field evaluation of some insecticides on whitefly (Trialeurodes vaporariorum) and predator (Macrolophus caliginosus) on brinjal and tomato plants. Asian J. Agric. Rural Dev. 2012, 2, 302-311.

48. Amarasekare, K.G.; Shearer, P.W. Laboratory bioassays to estimate the lethal and sublethal effects of various insecticides and fungicides on Deraeocoris brevis (Hemiptera: Miridae). J. Econ. Ėntomol. 2013, 106, 776-785. [CrossRef] [PubMed]

49. Müller, C. Impacts of sublethal insecticide exposure on insects-Facts and knowledge gaps. Basic Appl. Ecol. 2018, 30, 1-10. [CrossRef]

50. Daam, M.A.; Chelinho, S.; Niemeyer, J.; Owojori, O.; De Silva, P.M.C.; Sousa, J.P.; van Gestel, C.A.; Römbke, J. Environmental risk assessment of pesticides in tropical terrestrial ecosystems: Test procedures, current status and future perspectives. Ecotoxicol. Environ. Saf. 2019, 181, 534-547. [CrossRef]

51. Casida, J.E.; Durkin, K.A. Neuroactive insecticides: Targets, selectivity, resistance, and secondary effects. Annu. Rev. Ėntomol. 2013, 58, 99-117. [CrossRef] [PubMed]

52. Simon-Delso, N.; Amaralrogers, V.; Belzunces, L.P.; Bonmatin, J.M.; Chagnon, M.; Downs, C.; Furlan, L.; Gibbons, D.W.; Giorio, C.; Girolami, V.; et al. Systemic insecticides (neonicotinoids and fipronil): Trends, uses, mode of action and metabolites. Environ. Sci. Pollut. Res. 2015, 22, 5-34. [CrossRef]

53. Saha, S.; Mondal, R.; Mukherjee, S.; Sarkar, M.; Kole, R.K. Persistence of acetamiprid in paddy and soil under West Bengal agro-climatic conditions. Environ. Monit. Assess. 2017, 189, 150. [CrossRef]

54. Mostafiz, M.; Hassan, E.; Shim, J.-K.; Lee, K.-Y. Lethal and sublethal effects of methyl benzoate on the predatory bug Nesidiocoris tenuis. Insects 2020, 11, 377. [CrossRef] [PubMed]

55. Yamada, T.; Takahashi, H.; Hatano, R. A Novel insecticide, acetamiprid. In Nicotinoid Insecticides and the Nicotinic Acetylcholine Receptor; Yamamoto, I., Casida, J.E., Eds.; Springer: Tokyo, Japan, 1999; pp. 149-176. [CrossRef]

56. Kiriyama, K.; Itazu, Y.; Kagabu, S.; Nishimura, K. Insecticidal and neuroblocking activities of acetamiprid and related compounds. J. Pestic. Sci. 2003, 28, 8-17. [CrossRef]

57. Van de Veire, M.; Tirry, L. Side effects of pesticides on four species of beneficials used in IPM in glasshouse vegetable crops:" worst case" laboratory tests. IOBC-WPRS Bull. 2003, 26, 41-50.

58. Coll, M.; Guershon, M. Omnivory in terrestrial arthropods: Mixing plant and prey diets. Annu. Rev. Èntomol. 2002, 47, 267-297. [CrossRef]

59. Gammon, D.W.; Liu, Z.; Chandrasekaran, A.; El-Naggar, S.F.; Kuryshev, Y.A.; Jackson, S. Pyrethroid neurotoxicity studies with bifenthrin indicate a mixed Type I/II mode of action. Pest Manag. Sci. 2019, 75, 1190-1197. [CrossRef]

60. Rabelo, M.M.; Paula-Moraes, S.V.; Pereira, E.J.G.; Siegfried, B.D. Contrasting susceptibility of lepidopteran pests to diamide and pyrethroid insecticides in a region of overwintering and migratory intersection. Pest Manag. Sci. 2020, 76, 4240-4247. [CrossRef]

61. Soares, M.A.; Carvalho, G.A.; Campos, M.R.; Passos, L.C.; Haro, M.M.; Lavoir, A.; Biondi, A.; Zappalà, L.; Desneux, N. Detrimental sublethal effects hamper the effective use of natural and chemical pesticides in combination with a key natural enemy of Bemisia tabacion tomato. Pest Manag. Sci. 2020, 76, 3551-3559. [CrossRef]

62. Perdikis, D.; Psaroudaki, S.; Papadoulis, G. Compatibility of Nesidiocoris tenuis and Iphiseius degenerans with insecticides, miticides and fungicides used in tomato crops. Bull. Insectology 2020, 73, 181-192.

63. Prabhaker, N.; Naranjo, S.; Perring, T.; Castle, S. Comparative toxicities of newer and conventional insecticides: Against four generalist predator species. J. Econ. Èntomol. 2017, 110, 2630-2636. [CrossRef]

64. Stecca, C.D.S.; Da Silva, D.M.; Bueno, A.D.F.; Pasini, A.; Denez, M.D.; Andrade, K. Selectivity of insecticide use in soybean crop to the predator Podisus nigrispinus (Hemiptera: Pentatomidae). Semin. Ciências Agrárias 2017, 38, 3469-3480. [CrossRef] 
65. Collier, R.; Jukes, A.; Daniel, C.; Hommes, M. Ecological selectivity of pesticides and application methods. IOBC-WPRS Bull. 2016, 118, 94-98.

66. Duso, C.; Van Leeuwen, T.; Pozzebon, A. Improving the compatibility of pesticides and predatory mites: Recent findings on physiological and ecological selectivity. Curr. Opin. Insect Sci. 2020, 39, 63-68. [CrossRef]

67. Zhao, X.; Wu, C.; Wang, Y.; Cang, T.; Chen, L.; Yu, R.; Wang, Q. Assessment of toxicity risk of insecticides used in rice ecosystem on Trichogramma japonicum, an egg parasitoid of rice lepidopterans. J. Econ. Ėntomol. 2012, 105, 92-101. [CrossRef]

68. Wang, Y.; Wu, C.; Cang, T.; Yang, L.; Yu, W.; Zhao, X.; Wang, Q.; Cai, L. Toxicity risk of insecticides to the insect egg parasitoid Trichogramma evanescens Westwood (Hymenoptera: Trichogrammatidae). Pest Manag. Sci. 2014, 70, 398-404. [CrossRef] [PubMed]

69. Pazini, J.D.B.; Padilha, A.C.; Cagliari, D.; Bueno, F.A.; Rakes, M.; Zotti, M.J.; Martins, J.F.D.S.; Grützmacher, A.D. Differential impacts of pesticides on Euschistus heros (Hem.: Pentatomidae) and its parasitoid Telenomus podisi (Hym.: Platygastridae). Sci. Rep. 2019, 9, 1-10. [CrossRef] [PubMed]

70. Bueno, A.D.F.; Batistela, M.J.; Bueno, R.C.O.D.F.; França-Neto, J.D.B.; Nishikawa, M.A.N.; Filho, A.L. Effects of integrated pest management, biological control and prophylactic use of insecticides on the management and sustainability of soybean. Crop. Prot. 2011, 30, 937-945. [CrossRef] 